\title{
Values of the body mass index of adolescents from Romania reported to the number for hours of physical education practiced
}

\author{
Badicu G. ${ }^{\mathrm{ABCDE}}$ \\ Department of Physical Education and Special Motility, Faculty of Physical Education and Mountain Sports, \\ University Transilvania of Braşov, Romania
}

Authors' Contribution: A - Study design; B - Data collection; C - Statistical analysis; D - Manuscript Preparation; E - Funds Collection.

\begin{tabular}{|c|c|}
\hline \multicolumn{2}{|l|}{ Abstract } \\
\hline Purpose: & $\begin{array}{l}\text { he objective of this research is to show the values of the body mass index (BMI) of adolescents in Romania, } \\
\text { rasov county, reported to the number hours of physical education practiced. }\end{array}$ \\
\hline Material: & $\begin{array}{l}\text { The experiment was conducted between October } 2016 \text { - January } 2017 \text { in four high schools in Brasov county: } \\
\text { Andrei Şaguna High School, Andrei Mureşanu High School, Unirea High School and Sports High School. This } \\
\text { research was conducted on } 470 \text { pupils, of whom } 224 \text { are boys and } 246 \text { are girls, aged between } 14 \text { and 18. All } \\
\text { the subjects ( } n=470 \text { ) had their BMI calculated, depending on gender/grade/age and high school. }\end{array}$ \\
\hline Results: & $\begin{array}{l}\text { The results of the ANOVA One-Way analysis have shown a significant statistical difference between the four } \\
\text { high schools in terms of } B M I \text { average level }(F=36.493 ; p<0.001) \text {, in both boys and girls }(F=33.100 ; p<0.001) \text {. } \\
\text { Furthermore, also in terms of age, there are significant statistical differences between boys }(F=6.085 ; p<0.001) \\
\text { and girls }(F=3.920 ; p=0.004) \text {. The results of the Tukey test presented significant differences between the four } \\
\text { high schools, as far as subjects' gender is concerned as well. }\end{array}$ \\
\hline Conclusions: & $\begin{array}{l}\text { The study has shown that the values of the BMI are higher in pupils from Andrei Şaguna, Andrei Mureşanu, } \\
\text { Unirea high schools and lower in pupils from the Sports High School, both in boys and in girls. } \\
\text { adolescents, body mass index, pupils, high school. }\end{array}$ \\
\hline
\end{tabular}

\section{Introduction}

Problem of children and teenagers' physical training optimization is relevant for the last decades [1].

As we all know, sport has a major impact in our lives because it is an activity that affects our lifestyle, health as well as each individual's personality.

The practice of different sports activities not only helps us cope with the weight loss challenge, but also with daily stress, which became one of the most negative factors impacting our health, along with fatigue.

It is a known fact that practicing sports on a regular basis helps us lead a happier, more quiet, productive and stress-free life.

According to the Eurobarometer Survey carried out in 2013 [2], on the relation between sports and European countries and population, $60 \%$ of Romanians never practice, close to the European average of 59\%.

Currently, in Romania, 3 out of 10 children and adolescents are overweight and 8\% are obese. Romania is on the third place in Europe as far as child obesity is concerned, and the growing numbers of obese children make us expect to disastrous numbers in the upcoming years [3].

In an era of obesity, where children spend hours in a row in front of the computer, is required to take of some elementary measures which concern healthy development of preschools and school children, which become increasingly more sedentary.

The fact that physical education is no longer a priority in schools is not a novelty. In most of school's concentration is done on standardized tests and materials, (c) Badicu G., 2018

doi:10.15561/18189172.2018.0402 by minimizing the importance of physical education on children's health.

In Romanian schools, the food pupils eat consists mainly in croissants, biscuits, waffles or sandwiches soaked with sauces or unhealthy alternatives found in stores near the schools [4].

The consequences of obesity in children and adults are, amongst others, the inability of integrating into the community, the school and work environment, moving from one place to another or depression and suicide.

In this continuous struggle to control weight and maintain a good health, we should focus mostly on the type and quantity of the food and drinks we consume. In this matter, too little attention was paid to the amount of energy it takes to practice. It has been proven that $70 \%$ of the population in the western countries is not sufficiently active in order to have an optimal health and weight [5].

According to the findings of scientists, $75 \%$ of health issues are caused by inappropriate nutrition, unhealthy lifestyle and weight gain [5].

As far as the body mass index (BMI) is concerned, we mention that there are a number of researches that analyzed its values, both in teenagers, adults and in other categories of people [6-9].

A study conducted by Craig et al. [10], which examined BMI in pupils from Seventh Day Adventist schools in Australia, has shown low rates of overweight and obesity, but also higher rates of underweight, compared to the national standards. Statistical analyses of the study have proven that a lower BMI was associated with age, gender, regular breakfasts, a low consumption of soft drinks and regular practice. Also, pupils reported a frequent and high 
consumption of fruit, vegetables and cereals, compared to the Australian national standards.

Another study conducted by Cuceu et al. [11], demonstrates the role and effects of physical exercises, more precisely aerobics, on the BMI in first year female students at the North University Center of Baia Mare. The results of the study present significant differences of the BMI values between the experimental and the control groups. The aerobics has a more positive effect on the BMI in female students from the experimental group, compared to the students in the control group, who did not also practice aerobics, as part of their physical education classes.

The purpose of this research is to show the values of the BMI in teenagers in Romania, reported to the number for hours of physical education practiced.

The hypothesis of this research is based on the assumption that practicing on a regular basis affects in a positive manner the BMI of teenagers from urban areas.

\section{Material and methods}

Participants: This research was conducted on 470 pupils, of whom 224 are boys and 246 are girls, aged between 14 and 18 .

The subjects of this research were ninth, tenth, eleventh and twelfth grade pupils.

The pupils were distributed depending on gender and grade as follows: 121 ninth grade pupils (60 male, 61 female), 115 tenth grade pupils (52 male, 63 female), 118 eleventh grade pupils (58 male, 60 female), 116 twelfth grade pupils (54 male, 62 female).

The distribution for Andrei Saguna High School are: for ninth grade: 32 pupils (20 male, 12 female); tenth grade: 30 pupils (14 male, 16 female); eleventh grade: 29 pupils (12 male, 17 female); twelfth grade: 30 pupils (15 male, 15 female). For Andrei Mureşanu High School: ninth grade: 31 pupils (10 male, 21 female); tenth grade: 30 pupils (10 male, 20 female); eleventh grade: 32 pupils (15 male, 17 female); twelfth grade: 33 pupils (13 male, 20 female). For Unirea High School: ninth grade: 32 pupils (12 male, 20 female); tenth grade: 30 pupils (10 male, 20 female); eleventh grade: 31 pupils (15 male, 16 female); twelfth grade: 29 pupils (10 male, 19 female). The Sports High School: ninth grade: 26 pupils (18 male, 8 female); tenth grade: 25 pupils (18 male, 7 female); eleventh grade: 26 pupils (16 male, 10 female); twelfth grade: 24 pupils (16 male, 8 female).

Organization of the research: The experiment was conducted between October 2016 - January 2017, in four schools in Brasov County: Andrei Şaguna High School, Andrei Mureşanu High School, Unirea High School and Sports High School.

We mention that one single class from each grade was chosen for this experiment, respectively, from ninth to twelfth.

In the first phase of this experiment, we assessed the subjects' height and weight by the researcher. Based on the obtained results, we calculated the BMI [12], for each subject, depending on gender/grade/age and high school. The values of the BMI $\left(\mathrm{kg} / \mathrm{m}^{2}\right)$ were: less than 18.5 - underweight; 18.5 - 24.9 - normal; 25.0 - 29.9 overweight; greater than 30.0 - obese.

Statistical analyses: Statistical analyses were conducted by SPSS (IBM SPSS Statistics Version 20). In order to determine if there are significant differences in terms of BMI levels in boys and girls, between the different high schools participating in this study and depending on age, we used the ANOVA One-Way analysis. For the verification and comparison of significant differences between values pairs we applied the post-hoc Tukey test.

\section{Results}

Table 1 describes the characteristics of the study sample. The average and the standard deviation were calculated both for boys and girls, as far as the BMI (kg/ $\mathrm{m}^{2}$ ) is concerned, in each school, depending on age and the number of participants in the study.

Gender based analysis of the body mass index, depending on school type and age category

The results of the ANOVA One-Way analysis have shown that there is a significant difference, statistically speaking, between the four high schools, as far as average level of BMI is concerned ( $F=36.493$; $\mathrm{p}<0.001)$.

In order to verify between which of the four high schools the differences are significant, we applied the post-hoc Tukey (see Table 2). The results that were achieved highlighted significant statistical differences between the average level of BMI in boys from the Sports High School $(m=21.99 \pm 1.44)$, compared to the other high schools: "Andrei Şaguna" $(\mathrm{m}=23.90 \pm 1.72)$, "Andrei Mureşanu" $(\mathrm{m}=24.62 \pm 1.70)$ and "Unirea" National College ( $\mathrm{m}=24.51 \pm 1.39)$.

Also, the results of the ANOVA One-Way analysis have shown that there is a significant statistical difference between the four high schools participating in this study, as far as the level of BMI in girls is concerned. $(F=33.100$; $\mathrm{p}<0.001)$.

Female pupils from the Sports High School have an average body mass index of 21.03, whereas female pupils from the other high schools have a BMI average of over 23.7.

The results of the intergroup Tukey test (see Table $3)$ are significant $(p<0.001)$ for the comparison of the BMI level in girls from the Sports High School $(m=21.03 \pm 1.78)$, with the BMI level in girls from the other high schools: "Andrei Şaguna" $(m=24.07 \pm 2.08)$, "Andrei Mureşanu" $(\mathrm{m}=23.74 \pm 1.50)$ and "Unirea" High School $(\mathrm{m}=24.40 \pm 1.42)$.

The results of the ANOVA One-Way analysis have shown that there is a significant statistical difference between different age categories in terms of average level of BMI ( $\mathrm{F}=6.085 ; \mathrm{p}<0.001)$.

Results of the Tukey test (see Table 4) have highlighted significant statistical differences between BMI of 14 year-old boys $(m=22.50 \pm 1.78)$ on the one hand, and the BMI of 17 year-old boys, respectively 18 year-old boys $(m=24.17 \pm 1.48)$, on the other hand. Also, we have noticed significant differences between the BMI values on 15 
Table 1. Descriptive statistics of the participants

\begin{tabular}{|c|c|c|}
\hline Variables & $\begin{array}{l}\text { Male } \\
\text { Mean } \pm \text { SD }\end{array}$ & $\begin{array}{l}\text { Female } \\
\text { Mean } \pm \text { SD }\end{array}$ \\
\hline $\mathrm{N}$ & 224 & 246 \\
\hline $\mathrm{BMI}\left(\mathrm{kg} / \mathrm{m}^{2}\right)$ & $23.60 \pm 1.91$ & $23.66 \pm 1.98$ \\
\hline BMI depending on school: & & \\
\hline Andrei Şaguna National College & $23.90 \pm 1.72$ & $24.07 \pm 2.08$ \\
\hline Andrei Mureşanu High School & $24.62 \pm 1.70$ & $23.74 \pm 1,50$ \\
\hline Unirea National College & $24.51 \pm 1.39$ & $24.40 \pm 1.42$ \\
\hline $\begin{array}{l}\text { Sports High School } \\
\text { BMI depending on age: }\end{array}$ & $21.99 \pm 1.44$ & $21.03 \pm 1.78$ \\
\hline \multicolumn{3}{|l|}{ Andrei Şaguna National College } \\
\hline 14 years old & $22.53 \pm 1.84(n=20)$ & $22.91 \pm 4.06(n=12)$ \\
\hline 15 years old & $22.42 \pm 1.43(n=2)$ & $25.82 \pm 0.55(n=2)$ \\
\hline 16 years old & $24.0 \pm 0.87(n=12)$ & $23.95 \pm 1.21(n=16)$ \\
\hline 17 years old & $24.98 \pm 1.07(n=27)$ & $24.48 \pm 0.93(n=30)$ \\
\hline \multicolumn{3}{|l|}{ Andrei Mureşanu High School } \\
\hline 14 years old & $22.29 \pm 1.70(n=3)$ & $22.3 \pm 22.38(n=19)$ \\
\hline 15 years old & $25.65 \pm 3.47(n=7)$ & $23.95 \pm 0.21(n=2)$ \\
\hline 16 years old & $23.91 \pm 0.63(n=10)$ & $24.07 \pm 0.37(n=20)$ \\
\hline 17 years old & $24.52 \pm 0.94(n=17)$ & $24.28 \pm 0.69(n=37)$ \\
\hline 18 years old & $25.40 \pm 0.66(n=11)$ & \\
\hline \multicolumn{3}{|l|}{ Unirea National College } \\
\hline 15 years old & $24.18 \pm 2.47(n=12)$ & $24.59 \pm 2.48(n=20)$ \\
\hline 16 years old & $24.10 \pm 0.79(n=10)$ & $24.36 \pm 0.67(n=20)$ \\
\hline 17 years old & $24.58 \pm 0.56(n=15)$ & $24.43 \pm 0.69(n=21)$ \\
\hline 18 years old & $25.21 \pm 0.67(n=10)$ & $24.18 \pm 0.97(n=14)$ \\
\hline \multicolumn{3}{|l|}{ Sports High School } \\
\hline 15 years old & $20.73 \pm 0.95(n=18)$ & $21.11 \pm 3.62(n=8)$ \\
\hline 16 years old & $22.08 \pm 1.16(n=7)$ & $20.77 \pm 0.44(n=7)$ \\
\hline 17 years old & $22.25 \pm 1.54(n=25)$ & $20.94 \pm 0.55(n=10)$ \\
\hline 18 years old & $22.84 \pm 0.98(n=18)$ & $21.29 \pm 0.85(n=8)$ \\
\hline
\end{tabular}

*. The mean difference is significant at the 0.01 level. BMI = Body mass index.

Table 2. Body mass index in male subjects depending on the school - multiple comparisons ${ }^{a}$ with Tukey Hsd

\begin{tabular}{|c|c|c|c|c|c|c|}
\hline \multirow{2}{*}{ (I) School } & \multirow{2}{*}{ (J) School } & \multirow{2}{*}{$\begin{array}{l}\text { Mean } \\
\text { Difference (I-J) }\end{array}$} & \multirow{2}{*}{ Std. Error } & \multirow{2}{*}{ Sig. } & \multicolumn{2}{|c|}{ 95\% Confidence Interval } \\
\hline & & & & & Lower Bound & Upper Bound \\
\hline $\begin{array}{l}\text { "Andrei } \\
\text { Şaguna" }\end{array}$ & $\begin{array}{l}\text { "Andrei Mureşanu" High } \\
\text { School }\end{array}$ & -.71814 & .30361 & .087 & -1.5041 & .0678 \\
\hline National & "Unirea" National College & -.60762 & .30541 & .195 & -1.3983 & .1830 \\
\hline College & Sports High School & $1.91393^{*}$ & .27750 & .000 & 1.1955 & 2.6323 \\
\hline “Andrei & $\begin{array}{l}\text { “Andrei Şaguna” National } \\
\text { College }\end{array}$ & .71814 & .30361 & .087 & -.0678 & 1.5041 \\
\hline $\begin{array}{l}\text { Mureşanu" } \\
\text { High School }\end{array}$ & $\begin{array}{l}\text { "Unirea" National College } \\
\text { Sports High School }\end{array}$ & $\begin{array}{l}.11053 \\
2.63207^{*}\end{array}$ & $\begin{array}{l}.32291 \\
.29665\end{array}$ & $\begin{array}{l}.986 \\
.000\end{array}$ & $\begin{array}{l}-.7254 \\
1.8641\end{array}$ & $\begin{array}{l}.9465 \\
3.4000\end{array}$ \\
\hline “Unirea” & $\begin{array}{l}\text { "Andrei Şaguna” National } \\
\text { College }\end{array}$ & .60762 & .30541 & .195 & -.1830 & 1.3983 \\
\hline $\begin{array}{l}\text { National } \\
\text { College }\end{array}$ & $\begin{array}{l}\text { "Andrei Mureşanu" High } \\
\text { School }\end{array}$ & -.11053 & .32291 & .986 & -.9465 & .7254 \\
\hline & Sports High School & $2,52155^{*}$ & .29849 & .000 & 1.7488 & 3.2943 \\
\hline Sports High & $\begin{array}{l}\text { “Andrei Şaguna” National } \\
\text { College }\end{array}$ & $-1.91393^{*}$ & .27750 & .000 & -2.6323 & -1.1955 \\
\hline School & $\begin{array}{l}\text { “Andrei Mureşanu” High } \\
\text { School }\end{array}$ & $-2.63207^{*}$ & .29665 & .000 & -3.4000 & -1.8641 \\
\hline & "Unirea" National College & $-2.52155^{*}$ & .29849 & .000 & -3.2943 & -1.7488 \\
\hline
\end{tabular}

*. The mean difference is significant at the 0.05 level. a. Gender $=$ Male. 
Table 3. Body mass index in female subjects depending on the school - multiple comparisons ${ }^{a}$ with Tukey Hsd

\begin{tabular}{|c|c|c|c|c|c|c|}
\hline \multirow{2}{*}{ (I) School } & \multirow{2}{*}{ (J) School } & \multirow{2}{*}{$\begin{array}{l}\text { Mean } \\
\text { Difference (I-J) }\end{array}$} & \multirow{2}{*}{ Std. Error } & \multirow{2}{*}{ Sig. } & \multicolumn{2}{|c|}{ 95\% Confidence Interval } \\
\hline & & & & & Lower Bound & Upper Bound \\
\hline \multirow{3}{*}{$\begin{array}{l}\text { "Andrei } \\
\text { Şaguna" } \\
\text { National } \\
\text { College }\end{array}$} & “Andrei Mureşanu” High School & .32845 & .28835 & .666 & -.4175 & 1.0744 \\
\hline & "Unirea" National College & -.33725 & .29084 & .653 & -1.0896 & .4152 \\
\hline & Sports High School & $3.03565^{*}$ & .36392 & .000 & 2.0942 & 3.9771 \\
\hline \multirow{3}{*}{$\begin{array}{l}\text { "Andrei } \\
\text { Mureşanu" } \\
\text { High School }\end{array}$} & \multicolumn{2}{|c|}{ “Andrei Şaguna” National College-.32845 } & .28835 & .666 & -1.0744 & .4175 \\
\hline & "Unirea" National College & -.66569 & .27156 & .070 & -1.3682 & .0368 \\
\hline & Sports High School & $2.70720^{*}$ & .34870 & .000 & 1.8051 & 3.6093 \\
\hline \multirow{3}{*}{$\begin{array}{l}\text { “Unirea” } \\
\text { National } \\
\text { College }\end{array}$} & “Andrei Şaguna” National College & e.33725 & .29084 & .653 & -.4152 & 1.0896 \\
\hline & "Andrei Mureşanu” High School & .66569 & .27156 & .070 & -.0368 & 1.3682 \\
\hline & Sports High School & $3.37289^{*}$ & .35077 & .000 & 2.4655 & 4.2803 \\
\hline \multirow{3}{*}{$\begin{array}{l}\text { Sports High } \\
\text { School }\end{array}$} & $\begin{array}{l}\text { “Andrei Şaguna” National } \\
\text { College }\end{array}$ & $-3.03565^{*}$ & .36392 & .000 & -3.9771 & -2.0942 \\
\hline & “Andrei Mureşanu” High School & $-2.70720^{*}$ & .34870 & .000 & -3.6093 & -1.8051 \\
\hline & "Unirea" National College & $-3.37289^{*}$ & .35077 & .000 & -4.2803 & -2.4655 \\
\hline
\end{tabular}

*. The mean difference is significant at the 0.05 level. a. Gender $=$ Female.

Table 4. Body mass index in male subjects depending on age - multiple comparisons ${ }^{a}$ with Tukey Hsd

\begin{tabular}{|c|c|c|c|c|c|c|}
\hline \multirow{2}{*}{ (I) Age } & \multirow{2}{*}{ (J) Age } & \multirow{2}{*}{ Mean Difference (I-J) } & \multirow{2}{*}{ Std. Error } & \multirow{2}{*}{ Sig. } & \multicolumn{2}{|c|}{ 95\% Confidence Interval } \\
\hline & & & & & Lower Bound & Upper Bound \\
\hline \multirow{4}{*}{14} & 15 & -.26657 & .48139 & .981 & -1.5907 & 1.0576 \\
\hline & 16 & -1.16078 & .48139 & .116 & -2.4849 & .1634 \\
\hline & 17 & $-1.50686^{*}$ & .43091 & .005 & -2.6921 & -.3216 \\
\hline & 18 & $-1.66917^{*}$ & .48139 & .006 & -2.9933 & -.3450 \\
\hline \multirow{4}{*}{15} & 14 & .26657 & .48139 & .981 & -1.0576 & 1.5907 \\
\hline & 16 & -.89421 & .41465 & .200 & -2.0348 & .2463 \\
\hline & 17 & $-1.24029^{*}$ & .35480 & .005 & -2.2162 & -.2644 \\
\hline & 18 & $-1.40260^{*}$ & .41465 & .008 & -2.5431 & -.2621 \\
\hline \multirow{4}{*}{16} & 14 & 1.16078 & .48139 & .116 & -.1634 & 2.4849 \\
\hline & 15 & .89421 & .41465 & . 200 & -.2463 & 2.0348 \\
\hline & 17 & -.34608 & .35480 & .866 & -1.3220 & .6298 \\
\hline & 18 & -.50839 & .41465 & .736 & -1.6489 & .6322 \\
\hline \multirow{4}{*}{17} & 14 & $1.50686^{*}$ & .43091 & .005 & .3216 & 2.6921 \\
\hline & 15 & $1.24029^{*}$ & .35480 & .005 & .2644 & 2.2162 \\
\hline & 16 & .34608 & .35480 & .866 & -.6298 & 1.3220 \\
\hline & 18 & -.16231 & .35480 & .991 & -1.1382 & .8136 \\
\hline \multirow{4}{*}{18} & 14 & $1.66917^{*}$ & .48139 & .006 & .3450 & 2.9933 \\
\hline & 15 & $1.40260^{*}$ & .41465 & .008 & .2621 & 2.5431 \\
\hline & 16 & .50839 & .41465 & .736 & -.6322 & 1.6489 \\
\hline & 17 & .16231 & .35480 & .991 & -.8136 & 1.1382 \\
\hline
\end{tabular}

*. The mean difference is significant at the 0.05 level. a. Gender $=$ Male.

$(\mathrm{m}=22.77 \pm 2.87)$ and 17 year-old boys $(\mathrm{m}=24.01 \pm 1.61)$, as well as on 18 year-old boys $(\mathrm{m}=24.17 \pm 1.48)$.

The level of the BMI was also analyzed on girls, between the five age categories. The BMI average levels for the five age categories were in this order: 22.55, 23.76, 23.76, 24.03 and 23.13. The one-way variance analysis
(ANOVA) revealed a significant difference between these means F(4.241)=3.920; $p=0.004$. The measurement of the effect made via eta-square index shows a very insignificant effect, too little to be taken into consideration $(\eta=0.06)$ (see Table 5). 
Table 5. Body mass index in female subjects depending on age - multiple comparisons ${ }^{a}$ with Tukey Hsd

\begin{tabular}{lllllll}
\hline \multirow{2}{*}{ (I) Age } & (J) Age & Mean Difference (I-J) & Std. Error & Sig. & \multicolumn{2}{c}{$95 \%$ Confidence Interval } \\
Upper Bound
\end{tabular}

*. The mean difference is significant at the 0.05 level. a. Gender $=$ Female.

\section{Discussions}

The main findings of this study are:

1) there is a high number of overweight pupils from Şaguna, Andrei Mureşanu and Unirea high schools, whereas pupils from the Sports High School, in their vast majority, have a normal weight;

2) there are significant statistical differences between the BMI levels both depending on gender and on age categories, on all the pupils involved in the experiment.

Numerous studies examined the values of the BMI and of obesity in teenagers from different countries in the world. A UNICEF report 2009-2010 studied the health of a 11,13 and 15 year-old children in 29 countries and revealed that the highest percentage of obese children was registered in the USA (nearly 30\%) [13].

Siversten et al. [14] showed that there is evidence for a curvilinear relationship between BMI and both sleep duration and insomnia for girls, whereas the relationship was linear for boys. The study shows that compared to the average weekday sleep duration among adolescents in the normal weight range (6 hrs $29 \mathrm{~min}$ ), both underweight (5 hrs $48 \mathrm{~min}$ ), overweight (6 hrs $13 \mathrm{~min}$ ) and obese (5 hrs $57 \mathrm{~min}$ ) adolescents had shorter sleep duration.

A similar study was conducted by Halvorsen et al. [15], who demonstrates that overweight and obesity are associated with acne in girls aged 18 and 19, but the same association was not observed in boys. The prevalence of overweight was $9.5 \%$ in girls and $15.4 \%$ in boys. The prevalence of acne was $13.1 \%$ in girls and $14.0 \%$ in boys. Among those who were overweight or obese (BMI $\geq 25$ ), the prevalence of acne was $18.5 \%$ in girls and $13.6 \%$ in boys. In girls, there was an unadjusted OR of 2.1 (95\% CI, 1.4-3.3) between acne and overweight, and an adjusted OR of 2.0 (95\% CI 1.3-3.2). In boys, no significant associations were found between acne and BMI.

Another study conducted on 199135 adolescents from 36 countries and 72900 children from 17 countries provided information on their height, weight and fastfood consumption. This study shows that there is an association between increasing frequency of fast-food consumption and higher BMI in 6-7-year-old children, but this association was reversed in adolescents. This cross-sectional study provides evidence that among children from many different nations, fast-food consumption may contribute to weight gain. The reverse association observed in adolescents should be interpreted with caution, as the results may be affected by bias, particularly underreporting of fast-food consumption and reverse causation [16].

Adesina et al. [17] highlighted that factors which contributes to the weight problems of adolescents are the high socioeconomic class, higher maternal education, spending $>3$ hours a day watching television and frequent ingestion of snacks. Results showed that the prevalence of underweight, overweight, obesity and stunting was $6.4 \%, 6.3 \%, 1.8 \%$ and $5.4 \%$, respectively. The authors recommend the need for evaluation periodic of adolescents and health education to promote healthy eating habits and regular physical exercise as part of the School Health Programme. 
Some limitations of the present study have to be mentioned. Our findings are certainly limited by the relatively small sample size and the uncontrolled nature of the study design. The small sample size may decrease the power to detect statistically significant results in general. In addition, the assessment of the body mass index could have led to small inaccuracies which can allow for measurement errors.

The statistical power was further reduced when sexes were analyzed separately. Variations in body weight and height were found to widen along the age in the present study, and this is in line with nationally representative samples. Overall, the results of the present study should be replicated with a more representative sample to confirm the validity of the presented findings.

\section{Conclusions}

This study revealed that the values of the BMI are higher in pupils from Andrei Şaguna, Andrei Mureşanu and Unirea high school, this being due mainly to unhealthy nutrition, a sedentary lifestyle and other factors. On the other hand, we noticed on pupils from the Sports High School very good values of BMI, because of the many hours of sports activities included in the educational program of this domain.

For the other theoretical high schools involved in the study, the curriculum includes one hour of physical education per week, insufficient for a good health of teenagers and for fighting obesity.

In conclusion, it is worth mentioning that sports must be a part of each individual's daily life, because, besides the positive effects that it has on health, it also helps us fight weight gain.

\section{Conflict of interests}

The author declares that there is no conflict of interests.

\section{References}

1. Ivashchenko O, Khudolii O, Iermakov S, Harkusha S. Physical exercises' mastering level in classification of motor preparedness of 11-13 years old boys. Journal of Physical Education and Sports, 2017; 17(3): doi:10.7752/ jpes.2017.03158

2. New/Society. [Internet] 2018 Jan 2 [updated 2018 Jan 19; cited 2018 Apr 28]. Available from: http://adevarul.ro/news/ societate/eurobarometru-60-romani-nu-fac-niciodata-sport1_533068b40d133766a830b537/index.html (in Romanian)

3. Thought. Silent disease which affects three out of 10 children and adolescents in Romania. The explanation of a phenomenon that took us to the top 3 in Europe. 2014, [Internet] 2018 Jan 2 [updated 2018 Jan 19; cited 2018 Apr 28]. Available from: http://www.gandul.info/sanatate/boalatacuta-care-afecteaza-trei-din-10-copii-si-adolescenti-dinromania-explicatia-unui-fenomen-care-ne-a-dus-in-top-3-ineuropa-15114194 (in Romanian)

4. Observer. Figures alarming! A quarter of Romanian children are obese. [Internet] 2018 Jan 2 [updated 2018 Jan 19; cited 2018 Apr 28]. Available from: http://observator.tv/ social/cifre-alarmante-un-sfert-dintre-copiii-romani-suntobezi-211101.html (in Romanian)

5. Scri Group. The relationship between physical exercise, health and physical condition. [Internet] 2018 Jan 2 [updated 2018 Jan 19; cited 2018 Apr 28]. Available from: http://www. scrigroup.com/sanatate/sport/430/RELATIA-DINTREEXERCITIU-FIZIC13835.php (in Romanian)

6. Kahan D. Arab American College Students' Physical Activity and Body Composition. Research quarterly for exercise and sport, 2013; 82(1):118-128. doi:10.1080/02701367.2011.10 599728

7. Laukkanen A, Pesola AJ, Finni T, Sääkslahti A. Body Mass Index in the Early Years in Relation to Motor Coordination at the Age of 5-7 Years. Sports, 2017; 5(3):49-55. doi:10.3390/ sports5030049

8. Pasco J, Holloway K., Dobbins AG, Kotowicz M, Williams LJ, Brennan S. Body mass index and measures of body fat for defining obesity and underweight: a cross-sectional, population-based study. BMC Obesity, 2014; 23(1):9-15. doi:10.1186/2052-9538-1-9

9. Tsai MC, Chen W, Cheng YW, Wang CY, Chen GY, Hsu
TJ. Higher body mass index is a significant risk factor for acne formation in schoolchildren. European Journal of Dermatology, 2006; 16(3):251-253.

10.Craig BA, Morton DP, Kent LM, Butler TL, Rankin PM, Price KR. The Body Mass Index of Adolescents Attending Seventh-Day Adventist Schools in Australia: 2001-2012. Journal of School Health, 2017; 87(8):630-637. doi:10.1111/ josh.12535

11.Cuceu DA, Cuceu MD, Dumitrescu M. Study on the influence of exercises on the body mass index in the first year students. Palestrica of the third millennium - Civilization and Sport, 2014; 15(2):127-130.

12.BMI Calculator. [Internet] 2017 Nov 1 [updated 2018 Jan 1; cited 2018 Apr 8]. Available from: http://www. nutritionistcluj.ro/calculator-imc-indice-de-masa-corporalabmi (in Romanian)

13.Chang T, Barrett JM, Vosti SA. The Physical, Social, and Cultural Determinants of Obesity: An Empirical Study of the U.S, 2006, [Internet] 2018 Jan 2 [updated 2018 Jan 19; cited 2018 Apr 28]. Available from: http://ageconsearch.umn.edu/ bitstream/25279/1/pp061108.pdf

14.Siversten B, Pallesen S, Sand L, Hysing M. Sleep and body mass index in adolescence: results from a large populationbased study of Norwegianadolescents aged 16 to 19 years. BMC Pediatrics, 2014; 14:204-210. doi:10.1186/1471-243114-204

15.Halvorsen JA, Vleugels RA, Bjertness EA PopulationBased Study of Acne and Body Mass Index in Adolescents. JAMA Dermatology, 2012; 148(1):131-132. doi:10.1001/ archderm.148.1.131

16.Braithwaite I, Stewart AW, Hancox RJ, Beasley R, Murphy R, Mitchell EA. Fast-food consumption and body mass index in children and adolescents: an international cross-sectional study. BMJ Open, 2014; 4(12):e005813. doi:10.1136/ bmjopen-2014-005813

17.Adesina AF, Peterside O, Anochie I, Akani NA. Weight status of adolescents in secondary schools in port Harcourt using Body Mass Index (BMI). Italian Journal of Pediatrics, 2012; 38:31-37. doi:10.1186/1824-7288-38-31. 


\section{Information about the author:}

Badicu G.; https://orcid.org/0000-0003-4100-8765; georgian.badicu@unitbv.ro; Department of Physical Education and Special Motility, Faculty of Physical Education and Mountain Sports, University Transilvania of Braşov, 500068 Braşov, Romania.

Cite this article as: Badicu G. Values of the body mass index of adolescents from Romania reported to the number for hours of physical education practiced. Pedagogics, psychology, medical-biological problems of physical training and sports, 2018;22(4):177-183. doi:10.15561/18189172.2018.0402

The electronic version of this article is the complete one and can be found online at: http://www.sportpedagogy.org.ua/index.php/PPS/issue/archive

This is an Open Access article distributed under the terms of the Creative Commons Attribution License, which permits unrestricted use, distribution, and reproduction in any medium, provided the original work is properly cited (http://creativecommons.org/licenses/by/4.0/deed.en).

Received: 22.05.2018

Accepted: 16.06.2018; Published: 30.08.2018 